\title{
Fenomena Tukang Kredit Di Kampung (Studi Antropologi Ekonomi di Gampong Meunasah Blang Kecamatan Muara Dua Kota Lhokseumawe)
}

\author{
Mardiana \\ Prodi Antropologi FISIP Universitas Malikussaleh
}

\begin{abstract}
Abstrak
Artikel ini mengkaji tentang Fenomena Tukang Kredit Di Kampung, yang menjadi rumusan masalah dalam penelitian ini adalah bagaimana fenomena tukang kredit kampung di Gampong Meunasah Blang Kecamatan Muara Dua Kota Lhokseumawe, dan bagaimana masyarakat tertarik pada transaksi tukang kredit tersebut. Kredit merupakan suatu fasilitas keuangan yang memungkinkan seseorang atau badan usaha untuk meminjam uang untuk membeli produk dan membayarnya kembali dalam jangka waktu yang ditentukan Dengan menggunakan metode penelitiannya adalah pendekatan kualitatif dan yang menjadi tekhnik pengumpulan data melalui observasi dan wawancara. Observasi yang dilakukan adalah obsevasi non-partisipasi, observasi dilakukan untuk melihat bagaimana cara transaksi jual beli kredit dan bagaimana cara mengatasi pembeli yang sulit membayar cicilannya. Sedangkan wawancara dilakukan untuk menanyakan beberapa pertanyaan kepada tukang kredit, pelanggan yang membeli barang secara kredit dan masyarakat yang tidak membeli barang secara kredit. Adapun tujuan dilakukannya penelitian ini adalah untuk menjelaskan bagaimana pandangan masyarakat tentang fenomena perkreditan di Gampong Meunasah Blang. Dari hasil penelitian dapat disimpulkan bahwa masyarakat kelas menengah kebawah di Gampong ini menyukai transaksi jual beli barang secara kredit dikarenakan penghasilan mereka yang kurang mampu membeli barang secara tunai atau kontan hal ini diketahui dengan banyaknya barang yang mereka beli secara kredit tidak membeli secara tunai dipasar atau toko-toko yang menjual barang-barang rumah tangga.
\end{abstract}

Kata Kunci : fenomena, kredit, gampong, Lhokseumawe 


\section{Pendahuluan}

Di zaman modern seperti sekarang ini telah banyak penjualan barang sehingga sekarang telah banyak pemilik modal menjual barang dagangannya dengan cara membuat kredit atau angsuran. Cara kredit terbukti banyak dipilih oleh masyarakat zaman sekarang dalam memenuhi kebutuhannya. Contohnya di Gampong Meunasah Blang warganya ratarata berkehidupan cukup atau bahkan terkadang ada beberapa yang kurang dari cukup untuk memenuhi kehidupannya.

Terdapat lima orang tukang kredit di Gampong Meunasah Blang. Mereka terdiri dari pemilik modal dan anak buah atau sebagai perantara penjual barang dagangannya. Diantara lima orang tukang kredit ini ada yang menjual benda keperluan sehari-hari seperti baju daster, dan ada pulayang menjual barang yang diinginkan oleh pembeli. Dalam artian ini mereka tidak memiliki barang tersebut dirumahnya namun harus ke toko tempat yang benda yang diinginkannya. Tukang kredit yang menjual baju daster, atau pakaian lainnya di gampong ini hanyalah sebagai anak buah karena dia merupakan seorang penjaga toko disalah satu kios bertempat di Pasar Inpres. Dua diantara lainnya adalah Ibu Rumah Tangga yang menjual sprei, mukena, pakaian sehari-hari dan berpergian hanyalah anak buah dalam penjualan secara kredit ini (Hasil Observasi 20 April 2016).

Nur Fatoni perilaku tukang kredit yang terdapat di Kecamatan Cepiring Kabupaten Kendal dalam menjalankan bisnis kredit barangnya memiliki kesamaan dengan aturan-aturan jual beli dalam Islam. Islam memberikan solusi bagi pedagang yang menjual barang dagangannya dengan sistem bayar tunda, hukum sistem bayar tunda (kredit) dalam Islam adalah mubah yaitu Islam tidak memerlukan kondisi pribadi untuk melakukan transaksi jual beli bayar tunda. Penelitian ini menggunakan metode penelitian kualitatif dengan teknik pengumpulan datanya observasi dan wawancara. Dengan pendekatan yang digunakan adalah pendekatan sosiologis-filosofis. Penelitian yang dilakukan oleh Nur Fatoni dengan yang ingin penulis lakukan adalah sama-sama melakukan penelitian pada tukang kredit kampung namun Nur Fatoni melakukan penelitian lebih kepada pandangan agama Islam pada jual beli kredit sementara penelitian yang ingin penulis lakukan adalah pada kegiatan tukang kredit kampung.

Nurhafifah mengatakan bahwa perilaku pedagang di pasarMatang Kuli yang melakukan penimbunan barang adalah untuk memikirkan keuntungan semata, tujuan mereka melakukan perilaku itu adalah untuk menyelamatkan 
diri dan mempertahankan barang-barangnya sehingga mereka mampu bertahan dan bersaing dengan pedagang-pedagang lain yang berjualan di Pasar Matang Kuli tersebut. Penelitian ini menggunakan metode penelitian kualitatif. Pendekatan yang dilakukan oleh Nurhafifah adalah pendekatan etnografi yaitu sebuah model kualitatif dimana peneliti menjabarkan serta menginterprestasikan pola perilaku, kepercayaan, nilai serta bahasa yang dipahami dan digunakan oleh suatu kelompok. Penelitian yang dilakukan oleh Nurhafifah dengan yang ingin penulis lakukan adalah sama-sama melakukan penelitian pada pendagang yang menjual dagangannya sementara penelitian yang ingin penulis lakukan adalah pada kegiatan tukang kredit kampung.

Kredit merupakan suatu fasilitas keuangan yang memungkinkan seseorang atau badan usaha untuk meminjam uang untuk membeli produk dan membayarnya kembali dalam jangka waktu yang ditentukan. Kredit adalah penyediaan uang atau tagihan yang dapat dipersamakan dengan itu, berdasarkan persetujuan atau kesepakatan pinjam meminjam antara bank dengan pihak lain yang mewajibkan pihak peminjam untuk melunasi utangnya setelah jangka waktu tertentu dengan pemberian bunga. Budaya jasa adalah keseluruhan sistem gagasan, tindakan dan hasil karya manusia dari kehidupan masyarakat manapun dalam melakukan pelayanan kepada konsumen atau pembelinya. Budaya jasa berfokus pada terhadap pelayanan dan kepuasan konsumen. Pierre Bourdie mendefinisikan modal sosial sebagai sumber aktual dan potensial yang dimiliki oleh seorang berasal dari jaringan sosial yang terlembagakan serta berlangsung terus menerus dalam bentuk pengakuan dan perkenalan timbal balik (atau dengan kata lain: keanggotaan dalam kelompok sosial) yang memberikan kepada anggotanya berbagai bentuk dukungan kolektif.

\section{Metode Penelitian}

Penelitian ini menggunakan metode kualitatif dan menggunakan pendekatan Antropologi Ekonomi untuk melihat fenomena tukang kredit yang ada di gampong Meunasah Blang Kecamatan Muara Dua Kota Lhokseumawe. Proses Pengumpulan data melalui obsevasi dilakukan untuk mengetahui bagaimana transaksi dalam penjualan, apa yang menjadi latar belakang kreditur memberi barang dagangan secara kredit tanpa adanya syarat, dan bagaimana cara kreditur dalam mengatasi pembeli yang sulit membayar atau menunggak pembayarannya, serta bagaimana aktivitas para tukang kredit dalam kesehariannya mencari pembeli. Wawancara yang dilakukan ditujukan kepada para tukang kredit, pelanggan yang membelli barang 
secara kredit dan masyarakat yang tidak membeli barang secara kredit. Penelitian dilakukan pada bulan Mei tahun 2017 sampai Juni 2017.

\section{Hasil Penelitian}

\section{Lokasi Penelitian}

Gampong Meunasah Blang terdiri dari dua suku kata yaitu Meunasah yang artinya Meunasah atau tempat orang mengerjakan shalat dan Blang yang artinya Sawah atau tempat menanam padi. Jadi Meunasah Blang artinya adalah tempat untuk orang shalat yang berada ditengah sawah. Karena jaman dahulu wilayah ini merupakan persawahan warga dan di tengah persawahan tersebut terdapat meunasah. Inilah merupakan salah satu mitos yang menyebabkan gampong ini dinamakan gampong Meunasah Blang. Gampong Meunasah Blang memiliki Jumlah penduduk keseluruhannya 2226 jiwa yang terdiri dari 1120 jiwa laki-laki dan 1106 jiwa perempuan pada tahun 2017.

Dalam perkembangan pendidikan khususnya pendidikan agama, masyarakat di Gampong Meunasah Blang Kecamatan Muara Dua sudah berkembang pesat yaitu adanya berbagai kegiatan keagamaan di Meunasah, Balai-Balai Pengajian. Seiring dengan pesatnya kegiatan keagamaan terbentuknya pendidikan informal seperti tempat pengajian ALQuran dan Kitab. Namun di gampong ini banyak tempat-tempat pengajian yang sudah tidak difungsikan lagi. Adapula yang masih berfungsi namun kondisi balai pengajian yang sudah usang dimakan oleh waktu tanpa ada renovasi dari pemilik balai tersebut. Ringannya anggaran bulanan yang ditetapkan oleh pemilik balai tersebut membuat mereka tidak merenovasi balainya.

\section{Tukang Kredit Kampung}

Di Gampong Meunasah Blang, sebagian masyarakatnya suka berbelanja secara kredit. Sehingga di gampong ini terdapat tiga orang tukang kredit. Mayoritas tukang kredit di Gampong Meunasah Blang adalah wanita, mereka bekerja sebagai tukang kredit untuk meningkatkan pendapatkan ekonomi keluarga. Di samping itu, wanita juga memiliki tugas untuk memutuskan penggunaan uang dalam keluarga. Namun, lelaki tetap dianggap sebagai pencari nafkah utama yang harus bertanggung jawab memberikan penghasilannya kepada istri, untuk memenuhi kebutuhan sehari-hari. Oleh karena itu dari perspektif psikologi, wanita lebih mampu dan berpengalaman dalam menggunakan uang. Pengetahuan dan pengalaman yang dimiliki wanita dalam mengatur keuangan. 


\section{Nurhayati}

Nurhayati lahir di Meunasah Mee tanggal 12 September 1980. Sekarang ia telah berumur 40 tahun dan menjadi seorang ibu rumah tangga yang bekerja sampingan berjualan barang secara kredit. la merupakan seorang ibu dari tiga putra dan satu orang putri. Putra pertamanya berusia 21 tahun telah menyelesaikan pendidikan terakhirnya 3 tahun yang lalu. Putra keduanya usia 16 tahun baru memasuki sekolah menengah atas. Dan yang putri sekarang duduk dibangku sekolah pertama. Sementara yang terakhir baru berusia 3 tahun lebih. la telah menikah 22 tahun yang lalu dan telah tinggal di Gampong Meunasah Blang selama 15 tahun. Suami ibu Nurhayati adalah seorang supir dam truk dan sekarang telah memiliki dam truk sendiri. Ibu Nurhayati berdomisili di Dusun Lhok Jeumpet Gampong Meunasah Blang Kecamatan Muara Dua Kota Lhokseumawe.

Pendidikan terakhirnya adalah SMA. Ibu Nurhayati memulai usaha berjualan barang secara kredit 5 tahun yang lalu. la memilih berjualan secarakredit karena pekerjaan ini mempeloreh keuntungan yang besar. la merupakan pemilik modal, walaupun awalnya ia hanya berjualan barang yang murah seperti jilbab namun lambat laun usahanya terus berkembang. la tidak menggunakan uang modal dan keuntungan yang dipelorehnya dari usaha tersebut. la menggumpulkan uang usahanya dan mengembangkannya, bayangkan saja dahulunya ia hanya berjualan jilbab sekarang ia telah berjualan tuperware, pakaian sehari-hari mulai dari pakaian ibu-ibu seperti daster dan piyama hingga pakaian keseharian anakanak seperti kaos, gamis, blouse, jeans, pakaian bayi, kemeja, dan lain-lain.

Ibu Nurhayati memiliki banyak aktivitas dengan ibu-ibu gampong Meunasah Blang. Beberapa aktivitas yang dilakukannya yaitu seunujoh, sakmadiah, julo-julo, pengajian ibu-ibu setiap minggunya di Meunasah, dan masih banyak aktivitas lainnya yang dilakukan oleh lbu Nurhayati ini. Keseharian Ibu Nurhayati yaitu setelah shalat subuh ia mulai memasak untuk sarapan pagi anak-anak dan suaminya. Setelah itu iapun mengantarkan anak perempuannya yang masih SMP kesekolahnya di Cunda. Sepulangnya ia dari mengantar anaknya lbu Nurhayati membersihkan rumahnya. Kemudian ia memasak untuk makan siang atau malam nanti dan membuat kegiatan lain seperti merajut tas atau memperbaiki baju dia lakukan setelah kegiatan dirumah selesai dilakukan. Sore harinya ia mulai keluar untuk mengutip uang julo-julo dan cicilan pembayaran barang. Pada malam harinya ia gunakan untuk beristirahat atau berkumpul dengan keluarganya. 


\section{Nurhayati $Z$}

Nurhayati Z lahir di Lhokseumawe tahun 1972 yang sekarang berumur 45 tahun. la adalah seorang ibu rumah tangga yang bekerja sampingan berjualan barang secara kredit disela-sela aktivitas pekerjaan rumah tangganya. la merupakan seorang ibu dari dua orang putra dan satu orang putri. la telah menikah 25 tahun yang lalu dan telah tinggal di Gampong Meunasah Blang selama 20 tahun. Suami ibu Nurhayati adalah seorang supir dam truk. Ibu Nurhayati berdomisili di Dusun Lamloh Angen Gampong Meunasah Blang. Pendidikan terakhirnya adalah SMA.

Kehidupannya menjadi tukang kredit kampung berawal dari kesulitan hidup pada masa konflik di Aceh sehingga saya berinisiatif untuk membantu perekonomian keluarga. Kemudian ia meminta pekerjaan pada orang kelas menengah keatas untuk bersedia menjadi pemilik modal dari usaha kredit yang akan saya lakukan dengan imbalan $70 \%$ keuntungan untuk pemilik modal dan $30 \%$ keuntungan untuk saya. la dan suaminya telah memiliki sebuah rumah permanen, satu buah mobil dam truk dan dua buah sepeda motor. la juga telah memiliki sebuah rumah dengan ukuran $10 \times 10$ meter. Rumah permanen yang telah dilantai keramik dan diplasterkan ruang dalam dan rumahnya membuat ia menjadi lebih terlihat sukses dari pada tukang kredit lainnya yang ada di Gampong Meunasah Blang.

Jika lbu Nur hanya menjual tuperware dan pakaian maka lainnya dengan Ibu Yati. Ibu Yati hampir menjual seluruh barang perabotan rumah tangga secara kredit. Mulai dari pakaian sehari-hari, peralatan elektronik (blender, mixer, kulkas, dll), perabotan rumah tangga (tempat tidur, lemari, dll), barang pecah belah (piring kaca, gelas, dII). la telah menjalani usaha menjadi tukang kredit sejak 1999 yaitu selama 18 tahun yang lalu. Sekarang ia tidak hanya berjualan di hanya di Gampong Meunasah Blang namun telah merambah ke daerah-daerah lain yang berada di Kota Lhokseumawe ini.

\section{Aisyah Nur}

Aisyah Nur berumur 35 tahun, seorang ibu rumah tangga dan bekerja sampingan sebagai seorang tukang kredit dimana ia hanyalah seorang perantara atau anak buah dalam transaksi jual beli ini. la merupakan seorang ibu dari tiga orang putri, dan yang paling tua sekarang telah sekolah di bangku SMK kelas 2. Anaknya yang kedua kelas 2 Sekolah Menengah Pertama. Dan yang terakhir baru memasuki Sekolah Dasar yaitu berusia 6 tahun. la telah menikah 17 tahun yang lalu dan telah tinggal di Gampong Meunasah Blang selama 10 tahun. Suami ibu Nurhayati adalah seorang 
supir minibus 1300 dengan trayek Lhokseumawe-Kuala Simpang. Ibu Nurhayati berdomisili di Dusun Blang Geureubang Gampong Meunasah Blang. Pendidikan terakhirnya adalah SMA.

Kehidupannya menjadi tukang kredit kampung karena tawaran adiknya untuk berjualan sprei dan mukena. Saat itu adiknya sedang bersilaturahmi kerumahnya, kemudian ia menawarkan kepada ibu Aisyah untuk menjual barang dagangannya dan lbu Aisyah pun menerima tawaran tersebut dikarenakan ia hanya seorang ibu rumah tangga tidak memiliki aktivitas lainnya selain itu dan sampai sekarang ia masih berjualan barang secara kredit namun sekarang ia tidak lagi berjualan mukena, ia hanya menjual sprei.

Sekarang Ibu Aisyah Nur telah memiliki sebuah mobil L300 milik suaminya dan satu buah sepeda motor merek vario. la tinggal dirumahnya sendiri dengan ukuran rumah $6 \times 7$ meter dengan dua buah kamar dan mempunyai tanah ukuran $10 \times 40$ meter di gampong Meunasah Blang. Aktivitas yang dilakukan oleh lbu Aisyah yaitu dipagi hari ia mempersiapkan makan pagi untuk suami dan anak-anaknya sebelum berangkat sekolah. Setelah berangkat sekolah ia mulai membersihkan rumahnya, menyapu bagian luar dan dalam rumahnya. Setelah itu ia menyuci pakaian yang kotor, namun dia menyuci setiap dua hari sekali. Setelah semua pekerjaan tersebut selesai ia pun mulai memasak untuk dimakan di siang dan malam nanti. Pada sore harinya ia pun mulai berkumpul dengan tetangga yang berada disekitar rumahnya.

Pola kredit terbagi menjadi beberapa bagian yaitu seminggu sekali, dua minggu sekali atau sebulan sekali semua hal tersebut tergantung kesepakatan sang pembeli dengan tukang kredit. Karena dalam melakukan transaksi ini tidak semua pembeli membayar dalam satu waktu yang sama. $\mathrm{Hal}$ ini terjadi karena banyaknya kalangan pembeli yang beraneka ragam mata pencahariannya.Dimulai dari Pegawai Negeri Sipil atau pekerja pembantu rumah tangga yang mendapatkan gaji setiap satu bulan sekali berbeda halnya dengan pekerja buruh bangunan yang mendapatkan gajinya seminggu sekali atau penarik becak yang bepenghasilan setiap hari.

Dalam pembelian barang secara kredit terdapat jangka waktu pada proses pembayaran, sebagian besar dari mereka menerapkan pembayaran dengan jangka waktu paling telat adalah empat atau lima bulan untuk pembelian barang kisaran harga Rp 100.000,- hingga Rp 500.000. untuk barang yang harganya diatas lima ratus ribu rupiah atau satu juta rupiah 
mereka menetapkan pembayaran minimal setengah tahun atau maksimal satu tahun pembayarannya. Pembayaran tergantung dari awal saat membeli ingin dibayar setiap minggu atau perbulannya. Pembayaran juga dilihat dari pekerjaan pembeli barang apakah gajinya harian, mingguan atau bulanan.

Biasanya penjual dagangan secara angsuran selalu mencatat setiap transaksi yang dia lakukan dengan para pembelinya. Penjual mencatat siapa pembeli namanya, barang, tanggal dan dengan harga berapa pembayarannya. Penjual selalu membawa buku catatan penulisan barang penjualan saat melakukan transaksi penagihan kerumah pembeli barang jika sang pembeli tidak membayar cicilannya kerumah tukang kredit dan penjual selalu menulis setiap pembayaran yang dilakukan. Hal tersebut terus dilakukan hingga pembayarannya telah lunas sesuai harga yang disepakati.

Setiap menjalankan sebuah bisnis pasti ada kendala yang dihadapi oleh seorang pengusaha begitu juga usaha berdagang dengan cara kredit. Kendala yang dihadapi oleh tukang kredit meliputi pembeli yang sulit membayar cicilan barang yang telah dibelinya. Selain itu terdapat kendala yang lain dalam menjalankan bisnis ini yaitu barang yang dibeli rusak karena salah penggunaannya atau pemasangan oleh sang pembeli dikarenakan pembeli tidak mau di pasangkan barangnya sehingga terjadilah kerusakan barang yang mengakibatkan kami sebagai pemberi modal mengirim barang yang rusak tersebut ketoko service centernya yaitu di Medan. Hal ini diungkapkan oleh lbu Yati sebagai berikut:

"Suka dukanya yang saya hadapi dalam berusaha kredit barang yaitu jika saat mendapatkan pembeli yang mudah membayar cicilan pembayarannya membuat saya ingin terus menjalankan usaha ini namun disisi lainnya saya mengetahui setiap pekerjaan memiliki resiko atau kendala yang dihadapi begitu juga saya. Kendala yang saya hadapi selama berdagang kredit ini yaitu pembeli yang sulit membayar cicilannya. Ingin bertidak memaksa tidak mungkin dikarenakan kami saling mengenal sehingga solusi yang saya buat yaitu menunda waktu pembayarannya dan mendatangi rumah mereka setiap minggunya untuk menagih cicilannya." (Wawancara tanggal 16 Agustus 2017)

Lain halnya dengan Ibu Nurhayati yang mengatakan dilemanya menjadi seorang tukang kredit sebagai berikut:

"Dilema yang saya alami selama menjadi seorang tukang kredit yaitu yang pasti pembayaran cicilan yang dilakukan oleh pembeli terkadang 
menunda pembayarannya. Selain itu terkadang ada barang yang ingin dibeli oleh pembeli namun barang tersebut sedang kosong dan membuat saya harus pergi ke rumah tempat saya membeli pakaiannya dan mencari pakaian yang sesuai keinginan sang pembeli. Terkadang saya harus pergi hingga dua atau tiga kali ke rumah penjual pakaian itu jika belum mendapati pakaian yang cocok dengan pembeli tesebut". (Wawancara tanggal 10 Agustus 2017)

Ibu Aisyah mengutarakan pendapatnya mengenai dilemanya menjadi tukang kredit sebagai berikut:

"Terkadang yang membuat kita lelah menjadi tukang kredit ini pembeli yang macet pembayarannya dan tidak mendapatkan barang yang diinginkan oleh sang pembeli saat kita telah datang kerumahnya membawa semua barang yang ada dirumah hal itu juga menjadi dilemma menjadi tukang kredit." (wawancara 02 September 2017)

Semua bisnis pasti ada suka dukanya, karena semua manusia memiliki beragam sifat ada yang jujur dan ada yang kurang akan kejujurannya. Mereka yang jujur membuat para pemilik barang kreditur ini ingin terus menjalankan dan menambah barang yang dikreditkannya. Karena bagi masyarakat yang jujur mereka akan membayar cicilan barangnya tanpa harus kita mendatangi rumahnya. Berbeda dengan masyarakat yang kurang jujur mereka sering menunda-nunda pembayarannya walaupun sering di datangi rumahnya. Efek saling mengenal dan tinggal disatu daerah membuat para tukang kredit enggan memaksa cicilan pembayarannya. Mereka para tukang kredit lebih memilih menjaga hubungan individu dan tidak ingin dibicarakan oleh masyarakat daerah tersebut karena memaksa pembelinya membayar cicilannya. Hal tersebutlah yang membuat masyarakat lebih memilih berbelanja secara kredit kepada kreditur kampung dari pada kredit di toko-toko.

\section{Ketertarikan Masyarakat Pada Transaksi Kredit}

Kebutuhan Akan Barang Rumah Tangga

Harga barang yang semakin mahal membuat sebagian masyarakat memilih membeli barang secara kredit. Sebagian masyarakat yang membeli barang secara dicicil merupakan masyarakat yang tergolong kurang mampu. Mereka memilih berbelanja secara kredit agar tersedianya barang-barang dirumah tanpa harus menabung dahulu yang akan memakan waktu lebih lama dan merekapun harus menerima apa adanya yang terdapat dirumah. Berbeda bila membeli barang secara kredit, kita mendapatkan barang 
dahulu dan dapat menikmati barang tersebut baru kemudian membayar cicilan barangnya.

Mayoritas masyarakat yang pekerjaannya hanya penjualan es krim, penarik becak atau bekerja sebagai buruh bangunan membuat mereka ingin membeli barang secara kredit karena menurut mereka kehadiran para tukang kredit kampung ini dapat membantu kehidupan ekonomi mereka sebab pembayaran barang secara mencicil tidak langsung tunai. Seperti yang diungkapkan oleh lbu Zaitun seorang lbu Rumah Tangga sebagai berikut ini:

"Kehadiran para tukang kredit disini sedikit tidaknya membantu perekonomian keluarga saya, hal tersebut dikarenakan pekerjaan suami saya yang hanya seroang buruh bangunan atau penarik becak dihari jum'at. Selain hal tersebut ada alasan lain yang membuat kami membeli barang secara kredit yaitu kami dapat barang terlebih dahulu tanpa harus membayar dalam jumlah yang banyak dan pembayaran yang dilakukan setiap minggu tidak dalam sekali bayar dalam satu waktu walaupun saya mengetahui harga barang yang dibeli menjadi hampir dua kali lipat dari harga kontan yang dijual ditoko atau pasar." (Wawancara 28 Mei 2017)

Pekerjaan lbu Zaitun yang hanya lbu rumah tangga dan suami yang hanya seorang pekerja bangunan membuatnya harus memilih berbelanja secara kredit. Penghasilan suami yang satu harinya hanya Rp 85.000,- tidak termasuk makan dan biaya transportasi membuat mereka membeli barang secara kredit mulai dari barang kebutuhan sehari-hari seperti daster, piyama, jilbab dan pakaian bepergian hingga barang-barang elektonik seperti televisi, kipas angin, blender dan masih banyak lagi barang-barang yang dibeli olehnya dengan cara kredit.

Ibu Habsah salah seorang asisten rumah tangga dan buruh cuci di gampong mengatakan alasannya membeli barang secara kredit kepada saya sebagai berikut:

"Saya hanya seorang janda menafkahkan 2 orang anak saya yang masih menjadi tanggungan saya. Dari hasil pekerjaan saya yang menghasilkan penghasilan dari satu rumahnya $\mathrm{Rp} 500.000$ perbulan dan saya bekerja dalam 3 rumah. Setiap seminggu sekali saya menerima gaji dai pekerjaan saya. Saya tidak pandai mengelola uang masuk, karena saya termasuk orang yang boros untuk anak saya. Oleh karena itulah saya membeli barang secara kredit, saya dapat barang yang saya inginkan meski harus 
mencicil dari gaji saya setidaknya barang-barang dirumah saya terpenuhi dan tidak terasa begitu beban kepada saya karena tidak mengeluarkan uang dalam satu waktu yang begitu besar." (Wawancara tanggal 10 Juni 2017)

Hampir seluruh barang dirumah milik lbu Habsah adalah hasil membeli barang secara kredit. Karena lbu Habsah membeli barang mulai dari daster dan handuk yang digunakan sehari-hari, hingga barang-barang elektronik seperti parabola dan kulkas serta perabotan rumah tangga seperti lemari televisi ia beli secara kredit. Hal yang sama diungkapkan oleh Cut Hayati salah seorang mahasiswa SMA Negeri 5 Lhokseumawe dalam wawancara sebagai berikut:

"Berbelanja secara kredit membuat saya bisa memiliki banyak aksesoris di kamar saya, karena kalau beli di pasar saya harus nyimpan uang dulu berhari-hari bahkan berminggu-minggu. Sementara saya tidak bisa menyimpan uang, berapa uang yang saya terima oleh orang tua habis dalam hari itu juga."(Wawancara dengan Cut Hayati tanggal 05 Juni 2017)

Dari wawancara diatas menunjukkan bahwa memilih antara harus membeli secara kredit atau kontan terkadang pada beberapa orang membuatnya bingung. Mereka dihadapkan pada pilihan harus membayar lebih mahal karena harga pembayaran yang tinggi atau tidak mendapatkan barang karena tidak pintar mengelola keuangannya. Mereka terlalu royal dalam menggunakan uang hasil kerjanya sehingga untuk membeli barang secara kontan sulit untuk mereka. Karena hal tersebutlah yang membuat masyarakat kelas menengah kebawah memilih berbelanja secara kredit dari pada kontan. Terlebih lagi jika mau memasuki bulan suci ramadhan, banyak masyarakat yang memilih barang secara kredit disebabkan banyaknya pengeluaran yang akan mereka keluarkan selama bulan ramadhan hingga lebaran Idul Fitri tiba. Selain bulan Ramadhan terdapat bulan lain yang membuat masyarakat membeli barang secara kredit yaitu pada bulan-bulan sebelum dan sesudah tahun baru. Masyarakat pada bulan-bulan tersebut membeli handphone androiddan perabotan rumah tangga. Alasan dipilihnya bulan ini dikarenakan pada bulan ini masyarakat banyak mencari hiburan apakah tempat wisata atau lainnya.

Sebagian pandangan masyarakat berpandangan jelek kepada tukang kredit ini. Untuk menghindari reaksi-reaksi buruk dalam masyarakat, para tukang kredit berusaha memperlakukan klien mereka dengan cara yang manusiawi. Hal ini tidak berarti bahwa mereka mendekati nasabah tidak 
hanya dari pandangan kepentingan ekonomi semata tetapi juga pada basis hubungan-hubungan individual. Sering percakapan antara tukang kredit kepada pelanggan atau pembelinya melampaui pemenuhan hubungan ekonomi, dan berkaitan dengan masalah sehari-hari, khususnya masalah yang dihadapi oleh para pembeli atau pelanggannya.

Dengan kata lain, para tukang kredit berusaha untuk memberikan perhatian terhadap kesulitan-kesulitan yang dialami oleh para pelanggan atau pembelinya. Kadang-kadang para pelanggan atau pembeli juga membuat kesepakatan mengenai pembayaran cicilan, khususnya ketika pelanggan sedang mengalami masalah ekonomi yang berat. Misalnya, seorang lbu Rumah Tangga yang suaminya hanya pekerja tukang parkir atau buruh harian lepas dimana ia harus mengembalikan cicilan tiap bulannya. Namun dikarenakan ia baru melahirkan jadi tukang kredit mengundurkan tagihan pembayaran kreditnya. Pengalaman ini pernah terjadi oleh Ibu Rasima seorang lbu rumah tangga yang suaminya bekerja sebagai tukang parkir.

"Pendapat masyarakat bahwa tukang kredit itu jahat tidak seluruhnya benar. Ada beberapa hal yang baik dari mereka dan itu seharusnya diketahui oleh masyarakat. Contohnya saja saya seorang ibu rumah tangga yang suaminya bekerja sebagai tukang parkir dan memiliki bayi yang baru lahir. Bagi saya seorang IRT, mereka adalah salah satu kesempatan yang terlihat untuk mempeloreh kredit murah. Memang di lain hal dapat kita lihat harga barang yang mahal, tetapi dilain hal mereka sang tukang kredit juga memiliki resiko kehilangan uang juga tinggi, karena mereka tidak meminta jaminan saat melakukan transaksi jual beli secara kredit ini dahulunya. Misalnya jika kredit harus dikembalikan dalam waktu 3 bulan namun saya belum bisa membayarnya dalam waktu tiga bulan maka mereka akan memberikan toleransi untuk perpanjangan waktu pembayaran dan mereka juga tidak menambahkan harga barang saat pembayaran cicilannya tersendat atau macet." (wawancara tanggal 15 Juni 2017)

Namun hal lain yang berbeda disampaikan oleh Saiful Bahri seorang karyawan kontrak disalah satu perusahaan di kota Lhokseumawe mengatakan pendapatnya bahwa:

"Membeli barang secara kredit itu menurut saya merugikan, pribadi saya sendiri lebih memilih untuk tidak membeli barang secara kredit. Lebih baik 
saya tidak mempunyai barang apa-apa dirumah dahulu dari pada saya harus membeli barang secara kredit. " (Wawancara tanggal 10 Juni 2017)

Berdasarkan wawancara diatas menunjukkan bahwa tidak semua kalangan kelas menengah kebawah membeli barang secara kredit. Karena ada sebagian dari mereka membeli barang secara kontan. Mereka yang membeli barang secara kontan beranggapan bahwa membeli barang secara kredit merugikan selain karena harganya yang mahal, di bayang-bayangi dengan pembayaran kredit yang belum lunas membuat mereka tidak mau membeli barang secara kredit.

Membeli barang secara kredit terkadang dapat menguntungkan namun dapat juga dikatakan merugikan karena harga yang ditawarkan begitu mahal. Saat kita membeli barang secara tunai modal yang akan kita keluarkan lebih banyak dalam satu waktu. Berbeda dengan saat kita membeli barang secara kredit. Saat kita membeli barang secara kredit harga memang bisa menjadi hampir dua kali lipat dari harga kontan atau lunasnya namun disisi lain berbelanja secara kredit dapat menguntungkan karena pembayarannya yang tidak dalam satu waktu tetapi berulang bisa dalam setiap minggu ataupun setiap bulannya tergantung permintaan pembeli barang.

Pembeli yang membeli barang secara kredit tidak seluruhnya dari kalangan menengah kebawah atau masyarakat yang kurang mampu terkadang terdapat juga masyarakat yang tergolong mampu namun membeli barang secara kredit. Dan tidak seluruhnya masyarakat yang kurang mampu membeli barang secara kredit, ada beberapa dari mereka membeli secara tunai kepada tukang kredit ini. Karena tidak semua barang yang dijualnya secara kredit namun sebagian dari barang yang dibeli dijual kontan atau lunas.

Secara umum bisa dikatakan, kelompok nasabah terbesar yang mengandalkan jasa tukang kredit adalah orang-orang dari strata pendapatan rendah seperti contohnya tukang parkir, buruh cuci harian, pembantu rumah tangga, buruh bangunan dan masih banyak lagi pekerjaan lainnya yang berpendapatan rendah. Hal itu dianggap sebagai bukti yang jelas atas fakta bahwa penduduk kelas bawah membutuhkan kredit-kredit untuk membayar biaya hidup sehari-hari mereka. Dikarenakan pendapat mereka yang tergolong rendah yang terkadang hanya cukup untuk memenuhi kehidupan ekonomi sehari-hari mereka. Terkadang ada yang berpenghasilan tinggipun tetap memilih belanja secara kredit dikarenakan 
mereka bisa membeli barang lainnya dalam satu waktu tidak hanya satu buah barang tersebut. Meskipun kredit konsumsi banyak diminta oleh kelompok ini, mereka hampir tersentuh oleh kredit-kredit murah yang ditawarkan melalui bank-bank pemerintah. Dikarenakan masyarakat kelas menengah kebawah mereka tidak memiliki ilmu pengetahuan yang tinggi sehingga mereka kurang mengetahui tentang kredit-kredit yang ditawarkan oleh pemerintah atau toko-toko lainnya. Mereka lebih percaya kepada masyarakat yang memang telah dikenalnya dari pada pihak-pihak bank atau toko penyedia jasa penjualan barang secara kredit.

Selain dikarenakan ketidakpercayaan mereka yang telah saling mengenal bisa mengundur jangka waktu pembayaran berbeda dengan pihak-pihak toko karena terkadang terdapat pada toko-toko tertentu yang menaikkan harga cicilannya menjadi lebih tinggi dari minggu keminggunya hingga jika dalam kurun waktu satu bulan sang pembeli tidak membayar cicilan barangnya maka barang yang telah dibelinya akan diambil oleh pihak toko tersebut.

Dalam pembelian pada toko-toko yang menjual dagangannya secara kredit ini mempunyai beberapa syarat berbeda dengan tukang kredit kampung. Syarat yang mereka ajukan memang terbilang sama yaitu samasama mengajukan fotocopy KK dan KTP kepada pembeli yang ingin membeli secara kredit. Yang menjadi perbedaannya jika pada toko mereka akan melakukan survey lapangan dahulu baru setelah itu mereka akan memberi keputusan apakah mereka akan memberikan barang tersebut atau tidak. Jika pihak toko setuju maka mereka akan melanjutkan pada tahap pembayaran, pembayaran yang dilakukan di toko menurut jangka waktu bulan. Semakin tinggi bulan pembayarannya maka semakin tinggi bunga harga barang tersebut. Setelah tahapan pembayaran cicilan maka pembeli akan menandatangi surat persetujuan atas ketentuan-ketentuan pembelian barang secara kredit di toko tersebut. Berbeda dengan tukang kredit kampung yang tidak mematok pembayarannya pada setiap bulannya dan tidak menaikan harga barangnya jika pembelinya menunggak cicilannya.

\section{Kebutuhan Akan Ketinggalan Zaman}

Perkembangan zaman yang semakin canggih membuat beberapa masyarakat memilih membeli barang secara kredit. Barang yang dibeli mengikuti perkembangan zaman salah satunya adalah handphone. Tiap bulannya berbagai macam merek handphone muncul di televisi, majalah, handphone, dan lain sebagainya. Merek yang diproduksipun semakin 
canggih, bayangkan pada tahun 2007 handphone yang paling canggih hanya berkamerakan 5 megapixcel dan bentuknya masil tebal serta menunya yang masih terlalu biasa harganyapun pada saat itu bisa jutaan rupiah. Sementara dizaman 2017 sekarang kita bisa memiliki handphone dengan kamera 5 megapixcel dan dengan menu yang bisa diubah sesuai keinginan kita dengan harga satu jutaan bahkan beberapa handpone sekarang sudah tahan air berbeda dengan handphone dulu yang harga jutaan namun tidak tahan dengan air.

Sebagian masyarakat membeli handphone dikarenakan mereka ingin berfoto-foto dan bersosialita dengan teman-temannya. Seperti yang diungkapkan oleh Rosnita salah seorang pekerja toko pakaian sebagai berikut:

"Kalau ada handphone biasa lebih sering selfie-selfian dan bisa instagraman, facebookan dan googlean dan tampak lebih gimana gitu,, berbeda kalau gak ada handphone bosennya gak tau mau ngapain? Karena hal tersebut saya membeli handphone secara kredit dengan pembayaran melalui gaji kerja saya tiap bulannya" (Wawancara dengan Rosnita tanggal 03 September 2017)

Berdasarkan wawancara diatas menunjukkan bahwa tekhnologi dapat mempengaruhi seseorang dalam sikapnya. Sepuluh tahun yang lalu pada masyarakat kelas menengah kebawah kita sulit menemukan sebagian dari mereka yang menggunakan handphone namun sekarang tidak hanya oleh orang tua yang menggunakannya tapi anak kecilpun telah menggunakan handphone, tablet, atau bahkan laptop untuk bermain. Tekhnologi akan semakin canggih dari masa ke masa, masyarakat kelas menengah sulit mengikuti perkembangan tekhnologi tersebut. Namun kita tidak dapat menyangkal bahwa sebagian dari mereka rela membeli barang-barang elektronik seperti handphone dengan cara kredit untuk menunjang penampilan mereka agar terlihat lebih gaul dari pada menggunakan handphone biasa yang hanya bisa menjawab telepon dan SMS.

\section{Aktivitas Perkreditan}

Aktivitas perkreditan yang dilakukan oleh para tukang kredit yaitu membawa barang dagangannya kerumah pembeli yang ingin membeli barangnya jika barang tersebut berupa pakaian dan sprei. Namun jika barang yang diinginkan adalah barang-barang besar seperti perabotan rumah tangga (tempat tidur, lemari pakaian, lemari tivi, dan lain sebagainya) maka mereka akan dibawa ketoko tersebut. Sedangkan untuk barang elektronik seperti 
kulkas, blender, yong ma, dan lain-lain maka mereka akan mengatakan merek dan bagaimana klasifikasi barang tersebut kemudian barang akan dibeli oleh tukang kredit dan dijual kembali olehnya dengan harga dua kali lipat dari dia beli saat membeli secara kontan. Hal ini seperti yang diungkapkan oleh lbu Yati sebagai berikut:

"Aktivitas perkreditan ya kalau gak saya yang kerumah pembeli, pembeli yang akan datang kerumah saya untuk melihat barang yang akan dibelinya. Jika barang yang diinginkan tidak ada dirumah maka saya bersama dengannya akan ketoko tempat barang yang ingin dibeli oleh pembeli tersebut. Contohnya saja jika dia mau membeli lemari televise maka saya akan membawa dia ketoko itu dan mencari barang yang diinginkannya. Setelah menemui barang yang diinginkannya dengan harga yang sesuai dengan kesanggupannya maka sayapun membayar barang tersebut. Dan pada bulan depannya ia harus membayar cicilannya dengan kesepakatan yang telah disepakati bersama." (wawancara tanggal 16 Agustus 2017)

Ibu Aisyah Nur mengatakan saat wawancara sebagai berikut:

"Aktivitas perkreditannya yang saya lakukan adalah pembeli datang kerumah saya dan meminta lihat barang-barang yang saya kreditkan. Saya mengambilnya dan merekapun melihatnya jika mereka tertarik dengan barang saya mereka akan mengambil barang yang diinginkannya. Namun jika tidak ada yang disukainya maka mereka akan menanyakan kapan stock barang lagi agar mereka bisa datang lagi dan melihat barang-barang barunya." (wawancara tanggal 02 September 2017)

Ibu Nurhayati Mengutarakan aktivitas perkreditannya sebagai berikut:

"Sama halnya seperti dagang, pembeli datang mengutarakan keinginannya untuk membeli barang dan sayapun menunjukkan barangnya. Jika suka mereka akan mengambilnya, dan bila terjadi kesalahan ukuran maka mereka akan datang lagi dan menukarnya. Bahkan terkadang ada beberapa pembeli yang barangnya saya antarkan kerumahnya karena tidak adanya barang dirumah" (Wawancara tanggal 10 Agustus 2017)

Dari wawancara diatas dapat diketahui bahwa aktivitas yang dilakukan oleh tukang kredit ini meliputi menyediakan barang saat pembeli datang, mengantarkan pembeli ke barang yang diinginkannya serta mencari barang 
yang cocok dengan keinginan sang pembeli. Tukang kredit melayani pembelinya hingga mereka mendapatkan yang mereka inginkan dan hal ini hanya berlaku pada mereka yang memang telah diketahui bagaimana karakteristik sang pembeli tersebut. Terkadang ada beberapa pembeli datang kerumah pengangsur untuk membeli barang, jika barang sedang kosong atau tidak adanya stock dirumah maka mereka akan memberikan penjelasan kepada pembeli agar kembali esok harinya atau tukang kredit tersebut datang kerumah pembelinya. Hingga pembeli menemukan barang yang sesuai dengan keinginannya

Tidak semua pembeli yang datang diberikan langsung barang dagangannya, karena berdasarkan pengalaman penjualan ada beberapa tidak diberikan barang kreditan. Alasan mereka tidak memberi barang dagangan secara kredit kepada orang-orang tertentu yang memang dikenalnya adalah orang tersebut sulit membayar cicilan pembayaran barang yang dikreditkannya. Intinya mereka hanya memberi barang kepada siapa yang mereka percayai dan telah mengenal orangnya untuk barang yang dikreditkan dalam satuan harga $\mathrm{Rp} 50.000$,- sampai 400.000 ,- untuk diatas Rp. 400.000,- mereka memberi syarat seperti fotocopy KK dan KTP sebagai bahan pemberi peminjaman.

Kepercayaan penjual pada pembeli menjadi kekuatan bisnis tukang kredit. penjual menjaga prasangka baik kepada calon pembeli dan pembelinya. Calon pembeli atau pembeli yang memiliki hubungan dengan tukang kredit lain tidak menyurutkan niat para tukang kredit untuk menawarkan barang kepada calon pembeli dimaksud. Para tukang kredit juga tidak mempersoalkan, manakala pembeli, membeli barang yang lain dari tukang kredit lain, meskipun angsurannya belum lunas. Para tukang kredit menata niat untuk berdagang. Implementasinya ia melayani siapa saja dan tidak membeda-bedakan calon pembeli.

Dalam transaksi jual beli kredit hanya ada kesepakatan harga barang yang diperjual belikan. Para tukang kredit tidak mematok waktu pembayaran dan jumlah angsuran. Jumlah angsurannya sesuai kemauan pembeli. Penjual tidak menentukan angsuran yang wajib dibayar oleh pembeli. Harga yang disepakati tidak ditambah, meskipun ada pengunduran masa pembayaran. Uang muka bisa timbul jika pembeli langsung memberikan sejumlah uang angsurannya, namun hal seperti jarang terjadi. Dalam transaksi jual beli secara kredit tidak ada pembicaraan uang muka pada saat transaksi, biasanya mereka akan membayar cicilannya setiap minggu atau 
setiap bulan di tanggal yang telah di tentukan. Dalam memberikan barang kreditannya, para tukang kredit di Gampong Meunasah Blang mempunyai beberapa kriteria atau syarat-syarat dalam melakukan pembelian barang kepada dirinya diantaranya syarat tersebut meliputi:

a) Telah saling mengenal satu sama lainnya atau tukang kredit tersebut telah mengenal orang yang ingin membeli barangnya

b) Mengetahui apa pekerjaan sang pembeli atau keluarganya

c) Mengetahui sifat atau karakter kepribadian sang pembeli

d) Mengetahui tempat tinggal sang pembeli

e) Jika barang yang ingin dibeli adalah barang elektronik atau harga barang diatas Rp 500.000,- maka di berikan syarat lain yaitu fotocopy KK dan KTP sebagai jaminan pembelian barang.

Hal tersebut seperti yang diungkapkan oleh lbu Yati seorang tukang kredit yang berjualan mulai dari barang pakaian sehari-hari hingga barang-barang elektronik, dan perabotan rumah tangga sebagai berikut:

"Tidak semua masyarakat disini saya beri untuk membeli barang secara kredit, saya mempunyai beberapa syarat dalam memberi barang tersebut. Syaratnya meliputi saya tahu siapa dan apa pekerjaan pembeli barang kepada saya selain itu juga saya tahu sifat pembeli itu karena jika kita mengetahu sifat pembeli apakah ia tergolong sulit atau enggan membayar cicilan barang atau pembeli tersebut sering berhutang kepada orang lain. Serta saya juga harus tau dimana tempat tinggal pembeli barang kredit dengan saya dan jika harga barang yang dibeli telah mencapai $\mathrm{Rp} 500.000$,- maka saya tetapkan syarat lain yaitu adanya fotocopy KK dan KTP" (wawancara tanggal 12 Agustus 2017)

Hal yang sama diungkapkan oleh lbu Aisyah Nur yang mengatakan bahwa:

"Saya sangat berhati-hati dalam memilih pembeli yang ingin membeli barang kepada saya, saya biasanya melihat karakter orang tersebut. Apakah orang tesebut bisa dipercaya atau tidak karena dalam hal berdagang secara kredit ini modal yang akan kita keluarkan lumayan besar contohnya saya yang berdagang sprei yang harganya jika dibeli secara kredit mencapai Rp 450.000,-." (Wawancara 02 september 2017)

Berdasarkan hasil wawancara tersebut menunjukkan bahwa tukang kredit memiliki syarat-syarat dalam memberikan barang kreditannya. Hal ini berdasarkan pengalaman mereka dalam berdagang yang sering di tipu oleh 
sebagian pembelinya. Adapun barang-barang yang dijual secara kredit menurut para tukang kredit yaitu:

a. Ibu Nurhayati yang berjualan barang tuperware, pakaian sehari-hari, berpergian, jelbab dijual sebagian secara kredit dan sebagian lainnya tunai.

b. Ibu Aisyah Nur yang berjualan barang seperti sprei dan mukena.

c. Ibu Nurhayati Z (Ibu Yati) yang berjualan barang mulai dari pakaian sehari-hari seperti daster hingga pakaian gamis atau bepegian. barangbarang elektronik seperti mixer, blender, kulkas, handphone. Dan barang perabotan rumah tangga seperti lemari televisi, tempat tidur, lemari pakaian, dan lain-lain. Serta barang pecah belah seperti piring kaca, gelas, mangkok.

Dari ketiga tukang kredit diatas yang paling sering dikunjungi oleh pembeli adalah Ibu Nurhayati Z. Hal itu dikarenakan Ibu Nurhayati Z atau Ibu Yati ini menyediakan hampir seluruh barang yang ingin dicari tanpa harus bertanyatanya ditempat lainnya jika ingin membeli barang secara kredit. Ibu Yati menjual hampir segala barang rumah tangga, namun barang-barang tersebut tidak selalu tersedia dirumahnya contohnya tempat tidur atau handphone yang barang mahal dan tidak memungkinkan untuk barang tersebut ada dirumah. Ibu yati biasanya akan membawakan pembelinya ke toko barang yang diinginkannya namun tidak semua pembeli yang ikut bersama dengannya saat membeli barangnya. Ada beberapa pembeli yang ikut dengan apa keinginan lbu Yati, ia hanya mengatakan barang apa yang diinginkannya dan bagaimana modelnya saja. Selain dikarenakan ia menjual hampir seluruh barang rumah tangga, ia juga merupakan senior para tukang kredit di gampong ini. Seperti yang telah dijelaskan diatas ia telah memulai usaha berdagang jualan kredit ini sejak 18 tahun yang lalu bebeda dengan lbu Nurhayati dan lbu Aisyah Nur yang memulai usaha ini sejak 5 tahun lalu.

\section{Penutup}

Artikel memperlihatkan bahwa kebutuhan ekonomi yang semakin mahal membuat sebagian masyarakat kelas menengah kebawah memilih berbelanja secara kredit. Hal ini didasarkan atas keuangan masyarakat kelas menengah yang tergolong cukup untuk memenuhi kehidupan rumah tangganya. Disamping keterbatasan akan keuangan rumah tangga, tidak mampunya sebagian masyarakat dalam mengelola uang masuk membuat mereka membeli barang dengan pembayaran dicicil. Adanya tukang kredit di kampung ini sebagiannya karena mereka ingin membantu suaminya 
dalam menambah perekonomian rumah tangga. Dapat dilihat wanita yang bekerja membantu perekonomiannya tergolong lebih kaya dibanding para wanita yang hanya menjadi lbu rumah tangga tanpa bekerja. Dalam memberikan barang kreditannya para tukang kredit memiliki kriteria yang diantaranya telah saling mengenal dan mengetahui apa pekerjaan sang pembeli serta yang paling penting adalah mereka para tukang kredit mengetahui watak sang pembeli tersebut. Hal ini berdasarkan pada pengalaman mereka yang sebagian pembelinya sulit membayar cicilannya. 